https://doi.org/10.18485/iipe_postkovid.2021.ch12

\title{
EKONOMSKI IZAZOVI ZA EVROPSKU UNIJU U POST KOVID 19 PERIODU
}

\begin{abstract}
Andrea MATIJEVIĆ 1
Apstrakt: Kriza prouzrokovana pandemijom Kovid 19, pored zdravstvenih kreirala je dalekosežne ekonomske, političke i socijalne posledice na globalnom nivou. U ovom radu nastoji se ponuditi pregled posledica ove krize po ekonomske tokove Evropske unije. Posledice krize prouzrokovane pandemijom biće analizirane kroz vrednosti makroekonomskih indikatora za 2020. godinu: promene u stopama ekonomskog rasta posmatranog kroz rast realnog bruto društvenog proizvoda, promene u ulaznim i izlaznim tokovima stranih direktnih investicija, kao i promene obima međunarodne trgovine posmatrane kroz obim realizovanog uvoza i izvoza roba i usluga. Biće istaknuto da su posledice promena ovih makroekonomskih kretanja nejednako raspoređene među državama članicama EU i da su neke države iskusile veći pad ekonomskih performansi od drugih. Sumiranjem nalaza ovakve analize ponudiće se osnova za predviđanje ekonomskih kretanja u budućem periodu. Naime, kratkoročno posmatrano, optimistično se može očekivati da u 2022. godini Evropska unija reuspostavi pozitivne trajektorije rasta. $S$ druge strane, ako posmatramo na duži rok, da bi se kriza upravljanja Evropskom unijom, koja evidentno postoji i u ekonomskoj sferi, mogla razrešiti pozitivnim ishodom, potrebno je rešiti inherentne nestabilnosti evrozone. Osim ovoga, u cilju uspostavljanja osnova za ekonomski oporavak potrebno je da se na adekvatan način pristupi rešavanju problema u odnosima sa ekonomskim partnerima. U tom smislu, poseban značaj treba pridati unapređivanju trgovinskih i investicionih odnosa sa Sjedinjenim Američkim Državama i Kinom. EU, SAD i Kina danas predstavljaju tri stuba međunarodnog monetarnog sistema i uživaju najširi obim međusobnih ekonomskih odnosa na kojima se u najvećoj meri zasniva ekonomski uspeh sva tri ekonomska giganta pojedinačno posmatrano. Uprkos tome, postoji prostor za
\end{abstract}

\footnotetext{
${ }^{1}$ Istraživač pripravnik, Institut za političke studije, Beograd. E-mail: andrea.matijevic@ips.ac.rs. Rad je nastao u okviru naučno-istraživačke delatnosti Instituta za političke studije, koju finansira Ministarstvo prosvete, nauke i tehnološkog razvoja Republike Srbije.
} 
unapređenje odnosa EU kako sa SAD tako i sa Kinom, od čega bi u budućem periodu mogla zavisiti ne samo stabilnost EU per se već i globalna ekonomska stabilnost.

Ključne reči: Evropska unija, Kovid 19, ekonomski rast, strane direktne investicije, međunarodna trgovina, Sjedinjene Američke Države, Kina

\section{Uvod}

Evropska unija (u daljem tekstu EU) predstavlja kako političku tako i ekonomsku međunarodnu organizaciju regionalnog tipa. Preciznije, na teritoriji Evropske unije uspostavljen je poseban oblik regionalne ekonomske integracije koja se danas posmatra kao najznačajnija regionalna ekonomska integracija u svetskim razmerama i kao model integracije na koji se mnogi regioni u svetu ugledaju. Evolutivno posmatrano, EU je „prešla put“ od zone slobodne trgovine preko jedinstvenog evropskog tržišta (kompletiranog 1. januara 1993. godine) do kreiranja monetarne unije (kompletirane 1. januara 2002. godine). Monetarna unija, međutim, ne obuhvata sve države članice EU, poštujući suvereno pravo država da ukoliko žele čvršće ekonomsko povezivanje idu u dublju integraciju, a da one koje to ne žele ostanu u krugu labavije povezanosti. ${ }^{2}$ Uprkos tome, EU se najčešće u globalnim okvirima posmatra kao jedinstveni ekonomski akter (s tim što se pravi razlika između evrozone (Euro Area) kao evropske monetarne unije i EU kao jedinstvenog evropskog tržišta).

Period od početka 21. veka naovamo u najmanju ruku bio je turbulentan po EU. Osim problema na političkom nivou, ekonomski status Unije izazvan je u više navrata. Globalna finansijska kriza i kriza suverenih dugova evrozone ostavile su duboke tragove, što se može videti ne samo kroz nivoe realizovanog ekonomskog rasta, već i na osnovu drugih pokazatelja, poput pogoršanja pozicije EU u međunarodnoj trgovini i finansijama, unižavanja statusa evra u odnosu na ostale svetske valute po svim indikatorima itd. Najskorija dešavanja koja su počela krajem 2019. godine a koja i dalje, u 2021. godini, traju - kriza korona virusa, postavljaju pitanja dalekosežnosti ekonomskih posledica po EU.

Upravo zbog toga, jedan od osnovnih ciljeva ovog rada jeste da prikaže da su ekonomske posledice krize korona virusa po EU uporedive sa posledicama

\footnotetext{
2 Videti: Predrag Bjelić, Međunarodna trgovina, Ekonomski fakultet, Beograd, 2018, str.
} 389-395. 
globalne finansijske krize i krize evrozone. Ekonomske posledice biće identifikovane u kategorijama tzv. makroekonomskih troškova kovid krize, odnosno uticaja na realni ekonomski rast i međunarodnu trgovinsku i investicionu poziciju EU. Ovakav pregled daje se s namerom prikaza ekonomskih izazova sa kojima se EU mora suočiti u narednom periodu u cilju popravljanja ekonomske situacije prouzrokovane pandemijom.

U trenutku pisanja ovog rada već je publikovan značajan broj naučnih članaka i analiza u kojima se elaboriraju stvarne i potencijalne ekonomske posledice krize korona virusa po EU. Taj opus literature može se podeliti na izvore koji obrađuju posledice krize kroz uticaj na konkretne makroekonomske indikatore (ekonomski rast, stopu nezaposlenosti, uticaj na pojedine privredne sektore itd.) na nivou EU, i na one koji obrađuju pitanja efekta krize na institucionalni okvir EU, u kontekstu nerešenih institucionalnih problema i pre krize korona virusa. Relativno malo izvora obrađuje efekte krize na obe dimenzije. ${ }^{3}$ Stoga, osim analize makroekonomskih troškova rad dotiče i pitanja inherentnih nestabilnosti evrozone koje su već jednom prouzrokovale krizu s posledicama po sve države EU, a koje još uvek nisu, institucionalno posmatrano, u potpunosti razrešene na način koji bi predupređivao slična dešavanja u budućem periodu. Pored toga, čini se da postojećim analizama nedostaje međunarodna perspektiva, odnosno proučavanje odnosa EU sa najvažnijim ekonomskim partnerima u periodu krize. U tom smislu naročito je važan odnos sa SAD i Kinom iz više razloga. Ne samo da su SAD i Kina glavni trgovinski i

\footnotetext{
${ }^{3}$ Za analizu efekata krize po makroekonomske indikatore videti: Maryla Maliszewska, Aaditya Mattoo and Dominique van der Mensbrugghe, "The Potential Impact of COVID-19 on GDP and Trade: A Preliminary Assessment", World Bank Policy Research Working Paper No. 9211, April 2020. (analiza na globalnom nivou), ili: Julia Anderson, Simone Tagliapietra and Guntram B. Wolf, "Rebooting Europe: A Framework for a Post Covid-19 Economic Recovery", Policy Brief Issue 1, May 2020, Bruegel (na nivou EU). Akcenat na efekat krize po institucionalni okvir EU i može se uočiti u: Stella Ladi and Dimitris Tsarouhas, "EU economic governance and Covid-19: policy learning and windows of opportunity", Journal of European Integration, Volume 42, 2020, pp. 1041-1056, ili: Eugenio Salvati, "Crisis and Intergovernmental Retrenchment in the European Union? Framing the EU's Answer to the COVID-19 Pandemic", Chinese Political Science Review, volume 6 (2021), pp. 1-19. Efekte krize na obe dimenzije istaknute su u: Giuseppe Celi, Dario Guarascio and Annamaria Simonazzi, "A fragile and divided European Union meets Covid-19: further disintegration or 'Hamiltonian moment'?", Journal of Industrial and Business Economics, volume 47 (2020), pp. 411-424.
} 
investicioni partneri EU, zbog čega je naročito u kontekstu ekonomskog oporavka EU važno unapređivati odnose sa njima, već se EU, SAD i Kina posmatraju kao stubovi međunarodnog monetarnog sistema usled čega od njihovih međusobnih odnosa zavisi budućnost globalnog monetarnog poretka, a time i svetske ekonomije u celosti. Uopšte uzevši, analizom problema nastalih u najskorijem periodu i onih koji na duži rok predstavljaju kamen spoticanja EU, kako onih vezanih za unutrašnje makroekonomske performanse tako i onih koji se odnose na međunarodnu poziciju EU kao ekonomskog aktera, uspostavlja se holistički pristup istraživanju koji bi mogao predstavljati osnovu pri kreiranju optimalne strategije za buduće ekonomsko delovanje EU, tj. delovanje u postkovid 19 eri.

\section{Makroekonomske posledice krize Kovid 19 kao ekonomski izazov za EU}

\section{Ekonomski rast}

U godinama koje dolaze pred EU je dug put ekonomskog oporavka. Recesija uzrokovana korona virusom po svojim efektima uporediva je sa ekonomskim usporavanjem uzrokovanim globalnom finansijskom krizom i krizom suverenih dugova EU u sadejstvu, a po nekim nalazima ova potonja kriza čak ima i dublje posledice. ${ }^{4}$ Polazna osnova za utvrđivanje dubine recesivnih kretanja svakako jeste utvrđivanje stopa ekonomskog rasta na nivou EU, što je predstavljeno na grafikonu 1.1. kroz stope rasta realnog BDP-a za period od 2007. (godina početnih recesivnih kretanja u globalnoj finansijskoj krizi) do 2020. godine.

\footnotetext{
${ }^{4}$ Videti: Radovan Kovačević, „Svetska privreda, trgovina Evropske unije i robni izvoz Srbije pre pandemije korona virusa (Covid-19)", Ekonomske ideje i praksa, broj 38, septembar 2020, str. 7-25.
} 
Grafikon 1. Ekonomski rast EU 2007-2020 (rast realnog BDP-a u \%)

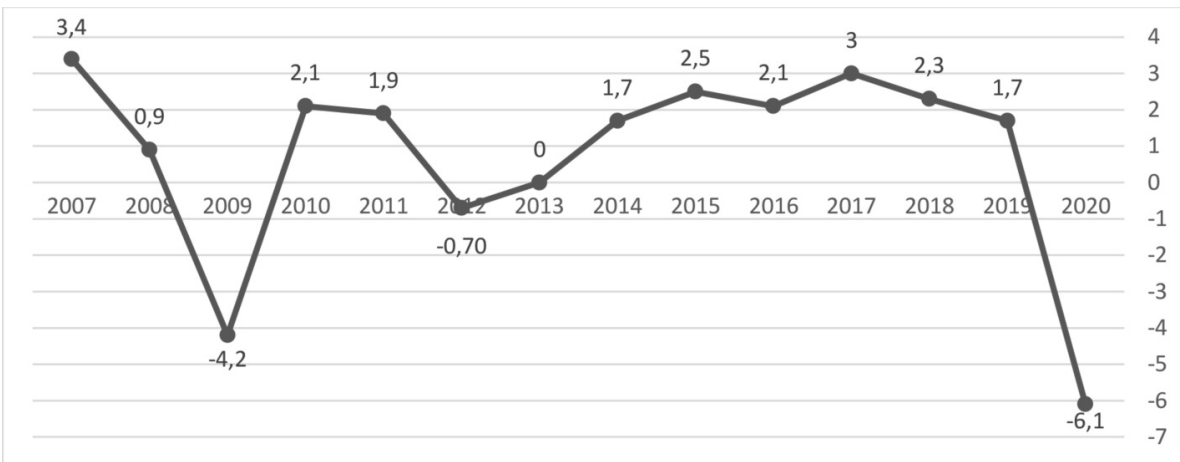

Izvor: International Monetary Fund, World Economic Outlook - Real GDP growth (annual percent change), April 2021. Internet: https://www.imf.org/external/datamapper/NGDP_ RPCH@WEO/WEOWORLD/EU , 10/06/2021.

Na grafikonu se može uočiti da je pad realnog BDP-a 2009. godine (koja se može posmatrati kao godina sadejstva efekata globalne finansijske krize 20072009. godine i krize evrozone, koja svoj uzlet stiče krajem 2009. godine) u odnosu na 2008. godinu $(-4,2 \%)$ bio manji nego što je to slučaj 2020. godine, kada je na godišnjem nivou došlo do još većeg pada $(-6,1 \%)$. Ovo vodi zaključku da je kriza korona virusa imala veće posledice po realan sektor EU od globalne finansijske krize i krize evrozone zajedno. ${ }^{5}$

Nadalje, iako se kriza korona virusa može smatrati simetričnim šokom, ipak se može uočiti da je taj simetričan šok kreirao heterogene posledice unutar EU. ${ }^{6}$ Posmatrano u kategorijama realnog bruto društvenog proizvoda, može se uočiti da je u 2020. godini od svih država članica EU jedino Irska realizovala rast realnog BDP-a u odnosu na prethodnu godinu od 2,5\%. U opsegu od $-3 \%$ do $0 \%$ rasta realnog BDP-a nalaze se samo Luksemburg (-1,3\%), Poljska (-2,7\%), Švedska $(-2,8 \%)$ i Finska i Estonija (obe po-2,9\% realizovanog rasta). Sve ostale države

\footnotetext{
${ }^{5}$ Za podatke o kretanju realnog BDP-a EU videti: International Monetary Fund, World Economic Outlook - Real GDP growth (annual percent change), April 2021. Internet: https://www.imf.org/external/datamapper/NGDP_RPCH@WEO/WEOWORLD/EU, 10/06/2021.

${ }^{6}$ Amélie Barbier-Gauchard et al., "Towards a more resilient European Union after the COVID19 crisis", Eurasian Economic Review, volume 11 (2021), p. 328.
} 
članice obeležio je pad realnog BDP-a veći od 3 procentualna poena, među kojima su najveći pad realizovale Španija (-11\%), Hrvatska (-9\%) i Grčka (-8,2\%). Osnovni faktor koji prema Otmaru Isingu (Otmar Issing), glavnom ekonomisti Evropske centralne banke, dovodi do toga da ovaj egzogeni šok kreira asimetrične posledice, posmatrajući ekonomske performanse država članica pojedinačno, jeste nivo zaduženosti država pre krize korona virusa. Države sa već visokim javnim dugom naišle su na veće poteškoće $u$ finansiranju mera potrebnih za stabilizaciju svojih ekonomija. Ističe se i da su veći ekonomski pad iskusile države sa ozbiljnijom zdravstvenom krizom i značajnijim merama „zaključavanja“ privrede. Takođe, važna je i privredna struktura država, jer nisu svi sektori podjednako pogođeni. S tim u vezi, može se primetiti da su najveći pad realnog BDP-a iskusile države koje su zavisne od turizma kao privredne grane posebno pogođene pandemijom. ${ }^{8}$

Uprkos ekstremnim efektima krize korona virusa po realni BDP EU, čini se da i dalje postoji razlog za opravdani optimizam. Prema procenama Međunarodnog monetarnog fonda (MMF), u 2021. godini biće realizovan rast realnog BDP-a na nivou EU od čak 4,4\%, a najveći broj država članica naći će se u opsegu 3-6\% rasta (uključujući i Španiju, koja će nakon godine sa najvećim padom realnog BDP-a prema predikcijama zabeležiti najveći rast ovog pokazatelja među svim državama članicama, rast od 6,4\%). Naravno, ne treba zaboraviti da stope rasta BDP-a predstavljaju rast na godišnjem nivou i da nije naročito teško realizovati visoke stope rasta nakon godine u kojoj je zabeležen drastičan pad ekonomske aktivnosti. Teško je očekivati da ekonomski rast koji bude realizovan 2021. godine nadoknadi gubitak rasta u 2020. godini. Ipak, prema projekcijama MMF-a se čini da će se EU već u 2022. godini reuspostaviti pozitivne trajektorije rasta (sa rastom od 3,9\% u odnosu na 2021), a predviđa se i da će se stopa rasta realnog BDP-a stabilizovati na 1,6\% u 2024. i 2025. Ovo sugeriše da iako je kriza korona virusa dovela do veće recesije od ekonomskih kriza 2007-2013. godine kratkoročno posmatrano, čini se da će nakon ove krize doći do bržeg oporavka ekonomske aktivnosti unutar EU. Da bi se ispitali efekti

\footnotetext{
7 Otmar Issing, "The COVID-19 crisis: A Hamilton moment for the European Union?", International Finance, Volume 23, Issue 2, Summer 2020, p. 340.

${ }^{8}$ Aleksandra Praščević, „,Ekonomski šok pandemije Covid 19 - prekretnica u globalnim ekonomskim kretanjima“, Ekonomske ideje i praksa, broj 37, jun 2020, str. 16.
} 
krize po međunarodne ekonomske odnose EU, naredni deo rada analizira promene međunarodne trgovinske i investicione pozicije EU.

\section{Međunarodna trgovina i međunarodni investicioni tokovi}

Kao što je i u slučaju proučavanja efekata krize korona virusa na ekonomski rast ove efekte svrsishodno bilo posmatrati u uporednoj perspektivi sa efektima kriza 2007-2013. godine, tako se i efekti krize Kovid 19 na međunarodnu trgovinu i investicije posmatraju komparativno sa efektima prethodnih kriza na ove pokazatelje. Podaci pokazuju da se, kao i u slučaju ekonomskog rasta, 2009. godina posebno ističe po negativnim kretanjima za EU i u kategorijama međunarodne trgovine i investicija, zbog čega se i u Tabelama 1.1. i 1.2. iznose vrednosti obima međunarodne trgovine (posmatrano kroz procentualne promene izvoza i uvoza roba i komercijalnih usluga) i investicionih tokova (posmatrano kroz procentualne promene ulaznih i izlaznih tokova stranih direktnih investicija - SDI) za 2009. i 2020. godinu.

Tabela 1. Procentualne promene obima robnog uvoza i izvoza EU za odabrane godine (u odnosu na prethodnu godinu) i procentualne promene obima izvoza i uvoza komercijalnih usluga za odabrane godine (u odnosu na isti mesec prethodne godine)

\begin{tabular}{|c|c|c|c|c|}
\hline 2009 & Robni izvoz & Robni uvoz & $\begin{array}{c}\text { Izvoz komercijalnih } \\
\text { usluga }\end{array}$ & $\begin{array}{c}\text { Uvoz komercijalnih } \\
\text { usluga }\end{array}$ \\
\hline 2020 & $-15 \%$ & $-14,5 \%$ & $\begin{array}{c}-22 \% \\
\text { (april 2009) }\end{array}$ & $\begin{array}{c}-23 \% \\
\text { (april 2009) }\end{array}$ \\
\hline$-8,8 \%$ & $-6,5 \%$ & $\begin{array}{c}-28 \% \\
\text { (april i maj 2020) }\end{array}$ & $\begin{array}{c}-29 \% \\
\text { (april 2020) }\end{array}$ \\
\hline
\end{tabular}

Izvor: World Trade Organization, WTO Data, n.d. Internet: https://data.wto.org/, 10/06/2021.

Može se zaključiti da je i 2009. i 2020. godine veći pad realizovan u kategorijama uvoza i izvoza komercijalnih usluga nego u oblasti robnog izvoza i uvoza. Veći pad robne razmene realizovan je 2009. nego 2020, ali su 2009. u oblasti razmene komercijalnih usluga realizovani bolji rezultati nego što je to slučaj sa 2020. godinom. Drugim rečima, u komparativnoj perspektivi 2009. više je pogođen robni uvoz i izvoz, a 2020. izvoz i uvoz komercijalnih usluga. Sektor 
komercijalnih usluga ujedno je pod uticajem krize korona virusa pretrpeo najveći pad obima uvoza i izvoza od početka 21. veka, generalno posmatrano, u odnosu na sve oblasti međunarodne trgovine $u$ tom periodu. $U$ najkraćem, obe krize nanele su veliku štetu identitetu EU kao trgovinskom gigantu na svetskom nivou.

Osim (barem kratkoročnog) umanjivanja trgovinskog značaja EU u globalnim okvirima, kriza korona virusa uticala je i na ,intra-trgovinske“ tokove. Naime, zatvaranje granica kojem su države članice pribegavale u cilju popravljanja epidemiološke situacije dovelo je do de facto suspenzije Šengenskog sporazuma i do uspostavljanja velikih prepreka slobodnom protoku roba i usluga kao osnovnih sloboda garantovanih uspostavljanjem jedinstvenog evropskog tržišta. ${ }^{9}$ To je za posledicu imalo pad trgovine između država članica EU i do ugrožavanja jednog od fundamentalnih stubova evropskog identiteta u nastajanju. ${ }^{10}$

Što se tiče međunarodne investicione pozicije EU, za potrebe ovog rada ona će biti posmatrana kroz promene obima ulaznih i izlaznih tokova SDI. SDI predstavljaju vrstu međunarodnih tokova kapitala koja podrazumeva da se rezident jedne ekonomije (investitor) uključuje kako u investiranje, tako i u menadžment kompanije registrovane u drugoj državi u cilju zadržavanja kontrole nad upotrebom plasiranog kapitala. Drugim rečima, svaka investicija koja dovodi do kupovine akcija u vrednosti od 10\% kompanije u koju se investira (ili preko) predstavlja direktnu investiciju. ${ }^{11}$

U slučaju EU podaci pokazuju da ako poredimo stepen realizovanih promena 2009. i 2020. može se uočiti da je kriza korona virusa imala drastično veći uticaj na ulazne i izlazne SDI EU od globalne finansijske krize i krize evrozone u sadejstvu - investicije u oba smera u toku 2020. godine opale su za više od 70\% u odnosu na prethodnu godinu.

\footnotetext{
${ }^{9}$ Amélie Barbier-Gauchard et al., "Towards a more resilient European Union after the COVID-19 crisis", op. cit., p. 322.

${ }^{10}$ Prema podacima Svetske trgovinske organizacije (STO), u 2020. godini je u odnosu na 2019. došlo do pada i robnog izvoza i robnog uvoza (-6,9\% i-7,5\%, respektivno). Procene STO o efektima krize Kovid 19 na trgovinu komercijalnim uslugama još uvek nisu dostupne.

${ }^{11}$ Dominik Salvatore, Međunarodna ekonomija, Centar za izdavačku delatnost Ekonomskog fakulteta, Beograd, 2014, str. 434.
} 
Tabela 2. Procentualne promene ulaznih i izlaznih tokova SDI u EU za odabrane godine (u odnosu na prethodnu godinu)

\begin{tabular}{|c|c|c|}
\hline & Izlazni SDI tokovi & Ulazni SDI tokovi \\
\hline 2009 & $-42 \%$ & $34 \%$ \\
\hline 2020 & $-77 \%$ & $-73 \%$ \\
\hline
\end{tabular}

Izvor: proračun autora na osnovu OECD, Foreign Direct Investment Statistics: Data, Analysis and Forecasts, April 2021. Internet: https://www.oecd.org/investment/statistics.htm, $10 / 06 / 2021 .^{12}$

Ako posmatramo promene na svetskom nivou, čini se da i kriza 2007-2013. i trenutna kriza korona virusa imaju uporedive posledice kada se radi o promenama u tokovima SDI. U 2009. obim ulaznih SDI tokova na svetskom nivou opao je za 37\%, a izlaznih za $43 \%$ u odnosu na 2008. godinu. ${ }^{13}$ U 2020. obim ulaznih SDI tokova opao je za 34\%, a izlaznih za $42 \%$ u odnosu na prethodnu godinu. Važno je posmatrati obim ulaznih i izlaznih tokova SDI u EU za obe posmatrane godine i u odnosu na one na svetskom nivou, i s tim u vezi potrebno je izneti dva važna zaključka.

Prvo, 2009. godine pad izlaznih tokova SDI pratio je prosek na globalnom nivou. Ono što se na prvi pogled čini čudnim jeste realizacija rasta ulaznih tokova SDI za čak $34 \%$ u godini kada dolazi do pada ovih tokova na svetskom nivou od čak 37\%. Ovo se može objasniti time što je nakon naglog pada ulaznih SDI od $60 \%$ u 2008. godini, 2009. godine realizovani rast zasnovan na rastu vlasničkog kapitala i reinvestirane zarade na globalnom nivou. Takođe, povrat na izlazne tokove SDI je nastavio da opada u odnosu na 2008. godinu, dok je povrat na ulazne tokove ostao stabilan u 2009. godini. ${ }^{14}$

\footnotetext{
${ }^{12}$ Napomena: lako je Konferencija Ujedinjenih nacija o trgovini i razvoju (United Nations Conference on Trade and Development - UNCTAD) najkredibilniji izvor podataka o tokovima SDI na godišnjem nivou, budući da izveštaj UNCTAD-a za 2020. godinu u momentu pisanja ovog rada još uvek nije publikovan, korišćena je alternativna baza podataka - OECD-ova baza.

${ }^{13}$ Videti: UNCTAD, World Investment Report 2010: Investing in a Low-Carbon Economy, New York and Geneva, 2010. Internet: https://unctad.org/system/files/official-document/ wir2010_en.pdf, 10/06/2021.

${ }^{14}$ Videti: Eurostat, Foreign direct investment statistics, June 2011. Internet: https://ec. europa.eu/eurostat/statistics-explained/index.php?title=Archive:Foreign_direct_ investment_statistics\&oldid=60641, 10/06/2021.
} 
Drugo, pad obima ulaznih i izlaznih tokova u EU za 2020. godinu je u drastično većem procentu od pada na svetskom nivou. Na osnovu dosadašnjeg pregleda može se zaključiti da je investiciona aktivnost značajno više pogođena krizom korona virusa od međunarodne trgovinske aktivnosti. Takođe, ako se ima u vidu da je investiciona pozicija EU za 2020. godinu kreirana ulaznim i izlaznim tokovima SDI, a posmatrano kroz vrednosti BDP-a, predstavljala $77 \%$ i 88\% BPD-a respektivno, i da su i u prethodnim godinama ulazni i izlazni tokovi SDI imali vrednost višu od 50\% BDP-a, postaje jasno koliko su SDI važne za EU i koliko EU zavisi od stabilnosti njihovih tokova. Pad priliva SDI naročito utiče na države članice koje su posebno zavisne od ovakvog priliva kapitala budući da nemaju dovoljno resursa za samostalno finansiranje ekonomskog razvoja, a time i ekonomskog oporavka od efekata krize korona virusa.

\section{Ostali izazovi za EU u postkovid eri}

$\mathrm{U}$ dosadašnjem izlaganju iznete su analize promena makroekonomskih pokazatelja kako bi se utvrdio efekat krize korona virusa na unutrašnju ekonomsku aktivnost EU i na njenu poziciju u međunarodnim ekonomskim tokovima. Ono što se može zaključiti jeste da EU ima pred sobom težak zadatak u cilju popravljanja ekonomske situacije i realizacije ekonomskog napretka u odnosu na 2020. godinu. Međutim, dodatni faktori koji nisu usko povezani sa efektima pandemije mogu osujetiti napore EU u realizaciji ciljeva ekonomskog oporavka. Ti faktori prvenstveno potiču od internih, moglo bi se reći destabilišućih tendencija u EU koji u dužem roku predstavljaju prepreke optimalnoj ekonomskoj aktivnosti. Takođe, unapređenje međunarodne trgovinske i investicione pozicije EU zavisi od odnosa sa najznačajnijim ekonomskim partnerima, a trenutna slika tih odnosa prikazuje izvesne sporove vezane za širi socio-ekonomski kontekst.

\section{Inherentna nestabilnost evrozone}

Da bi se na sveobuhvatan način ukazalo na problem koji sprečava EU u realizaciji boljih ekonomskih rezultata, ponovo je svrsishodno trenutni kontekst delovanja EU u cilju saniranja posledica krize korona virusa posmatrati u komparativnoj perspektivi sa delovanjem EU u periodu nakon krize suverenih dugova, tj. krize evrozone (kraj 2009-2013). Naime, prema pojedinim analizama, 
ekonomska stagnacija pogodila je EU tako da je i pre krize korona virusa došlo do pada ekonomske aktivnosti. ${ }^{15}$ Osim rastućeg protekcionizma na globalnom nivou, koji je doveo do pada ekonomske aktivnosti 2018. i 2019. godine, u konkretnom slučaju EU, ovo sugeriše da je EU „ušla“ u pandemiju sa još uvek u potpunosti nerešenim posledicama krize evrozone. ${ }^{16}$ Neuspeh u koordinisanju makroekonomskih politika na nivou evrozone sprečio je potpuni oporavak EU od krize suverenih dugova, usled čega se zapravo postavlja pitanje kako očekivati da ove institucionalne prepreke neće dovesti do neuspeha u kreiranju strategije za oporavak od krize korona virusa, kao što je to bio slučaj u krizi evrozone?

Krenimo najpre od krize evrozone, njenih osnovnih uzroka i institucionalnih posledica. Opus literature koja se bavi krizom evrozone je toliko obiman da se s razlogom može govoriti o „krizologiji“ ${ }^{17}$ Posebnost ove krize leži u velikom broju njenih uzroka (za razliku od prethodnih kriza EU koje su imale mahom singularne izvore), ali i u dalekosežnosti njenih ne samo ekonomskih već i političkih, socijalnih i drugih tipova posledica. ${ }^{18}$

Najkraće rečeno, kriza evrozone zapravo je kriza suverenih dugova. Povod za izbijanje krize je priznanje nove vlade Grčke o stvarnom stanju duga krajem 2009. godine, što je potreslo finansijsko tržište EU. Odgovor na paniku i visoko zaduživanje sastojao se u pokušaju da se intervencijama smanji mogućnost otvorenog bankrota pojedinih zemalja u okviru evrozone, a pored Grčke naročito su se u tom smislu istakle i Portugal, Italija, Irska i Španija (tzv. PIIGS države). Intervencije u cilju smirivanja krize koje su preduzele zemlje evrozone nisu dale rezultate. Štaviše, kriza se proširila i na druge države. Osnovni problem je što su ostale države bile onemogućene da efekte apresijacije koje su pogodile njihove ekonomije ublaže devalvacijom (ovakav gubitak monetarnog suvereniteta posledica je članstva u monetarnoj uniji). Kriza evrozone otkrila je dva fundamentalna problema: preveliku zaduženost „evropskog juga“ i nepostojanje supervizije na nivou evrozone, odnosno odsustvo bankarske unije. Drugim rečima,

\footnotetext{
${ }^{15}$ Radovan Kovačević, „Svetska privreda, trgovina Evropske unije i robni izvoz Srbije pre pandemije korona virusa (Covid-19)", op. cit., str. 10-13.

${ }^{16}$ Ibid., str. 9.

${ }_{17}$ Slobodan Samardžić, „Jedan političko-realistički pogled na današnju Evropu i mesto Nemačke u njoj", pogovor u: Herfrid Minkler, Sila u središtu: Novi zadaci Nemačke u Evropi, Albatros Plus, Beograd, 2016, str. 143.

${ }^{18}$ Slobodan Samardžić, „Evropska unija između krize i dezintegracije“, Pravo i društvo, Broj 1, 2012, str. 14.
} 
kriza je otkrila da je monetarna unija nedovršen projekat, i da Evrozoni nedostaje zajmodavac u poslednjoj instanci za najugroženije države (lender of last resort), mogućnost fleksibilnosti u reakciji na šokove i zajedničkog garantovanja dugova, kao i mogućnost fiskalnih transfera. Stoga se u odgovoru na krizu pristupilo realizaciji plana koji je kreiran kako bi se (barem pokušali) nadomestiti do tada nedostatni elementi monetarne unije. Evropska centralna banka (ECB) ponela se kao pravi zajmodavac u poslednjoj instanci, i to ne samo kroz otkupe državnih $i$ privatnih hartija od vrednosti, putem kojih je do februara 2012. u ove svrhe utrošila 220 milijardi evra istovremeno apsorbujući istu količinu novca kako bi sprečila inflaciju. U decembru 2011. ECB je počela najveću u istoriji evra infuziju likvidnosti u bankarski sistem za potrebe dugoročnih operacija refinansiranja. Takođe, u julu 2012. godine uspostavljen je Evropski stabilizacioni mehanizam (European Stability Mechanism - ESM), kao međuvladino telo sa kapacitetom od 500 milijardi evra za neophodne intervencije. Kreirana je i Bankarska unija Evropske unije (Banking Union of the European Union) kao telo za nadzor nad nivoima zaduženosti svih država članica EU. ${ }^{19}$

Ipak, sve ovo nije bilo dovoljno za brz ekonomski oporavak evrozone. Alternativni predlozi podrazumevali su uspostavljanje evroobveznica, kojima bi se izvršila kompletna supstitucija svih državnih dugova država evrozone u hartije od vrednosti koje se mogu prodati. Problem je u tome što bi se na taj način opteretile jače privrede sa manjim deficitima i što bi to išlo u prilog onima koji se nisu istakli finansijskom disciplinom. Odsustvo fiskalne koordinacije identifikuje se dakle kao osnovni problem evrozone. lako su 2012. godine sve tadašnje članice EU (sem Češke i Velike Britanije) zaključile Ugovor o fiskalnoj stabilnosti (Fiscal Stability Treaty) u cilju podsticanja fiskalne discipline, koji je podrazumevao još rigoroznije kriterijume od Pakta za stabilnost i rast (Stability and Growth Pact) (između ostalog i kazne za prekršioce odredbi), države članice EU nisu uspele da izdejstvuju fiskalnu koordinaciju koja bi dovela do efektivnog izlaska iz recesije uzrokovane krizom evrozone. Kriza evrozone okarakterisana je kao „velika kriza“, kao „kriza dezintegracije“ EU po svojoj izrazitoj tendenciji. ${ }^{20}$

\footnotetext{
${ }^{19}$ Paul R. Krugman, Maurice Obstfeld and Marc J. Melitz, International Economics - Theory and Policy, Pearson Education Limited, 2018, pp. 704-714.

${ }^{20}$ Izraz „velika kriza“ preuzet iz Slobodan Samardžić, „Evropska unija u lavirintu krize“, u: Slobodan Samardžić i Ivana Radić-Milosavljević (ur.), Kriza Evropske unije, Službeni glasnik,
} 
Sa ovakvim problemom ekonomskog upravljanja EU ušlo se i u krizu korona virusa. U odgovoru na ovu krizu, ECB može naići na značajne poteškoće, budući da heterogenost ekonomija evrozone može umanjiti efikasnost zajedničke monetarne politike - teško je jedinstvenu monetarnu politiku koordinisati sa fiskalnim politikama na nivou svake pojedinačne države članice. ${ }^{21}$ Čini se da je i kriza Evrozone pokazala da su sve mere sanacije posledica krize gotovo kozmetičkog karaktera ukoliko ne dođe do većeg nivoa makroekonomske koordinacije. Za postizanje ovog cilja, međutim, potrebna je izmena osnivačkih ugovora EU. Svi pritisci Evropske komisije i drugih EU zvaničnika za uspostavljanjem višeg nivoa fiskalne integracije, a bez izmene ugovora, mogu umanjiti legitimitet EU institucija i time naneti više štete nego koristi. ${ }^{22}$ Ovo naročito dobija na značaju ako se ima u vidu da su nedavno sprovedene studije ukazale na dodatni rast heterogenosti među članicama monetarne unije za vreme korona virusa. ${ }^{23}$

Kriza korona virusa dovela je do najvećeg rasta javnog duga u najvažnijim EU ekonomijama, usled čega raste i opasnost od ponavljanja scenarija krize evrozone. Sličnost sa krizom suverenih dugova može se uočiti i u pogledu pregovora o strategiji ekonomskog oporavka, i s tim u vezi različitih sporenja koja su se javila između EU zvaničnika ponovo, deset godina nakon što se pokazalo da odsustvo dogovora o strategiji oporavka najviše i usporava taj oporavak. ${ }^{24}$ Važno je napomenuti i to da je kriza evrozone, odnosno politički odgovori na nju, podstakla rast evroskepticizma. ${ }^{25}$ Budući da su ekonomske posledice krize

Beograd, 2013, str. 15. Kriza evrozone ocenjena je kao kriza dezintegracije u: Slobodan Samardžić, „Evropska unija između krize i dezintegracije“, op. cit., str. 14.

${ }^{21}$ Amélie Barbier-Gauchard et al., "Towards a more resilient European Union after the COVID-19 crisis", op. cit., pp. 328-329.

${ }^{22}$ Otmar Issing, "The COVID-19 crisis: A Hamilton moment for the European Union?", op. cit., p. 345.

${ }^{23}$ Videti: Antoine Camous, Grégory Claeys, "The Evolution of European Economic Institutions During the Covid-19 Crisis", European Policy Analysis, 2020:6, pp. 328-341.

${ }^{24}$ Amélie Barbier-Gauchard et al., "Towards a more resilient European Union after the COVID-19 crisis", op. cit., p. 334.

${ }^{25}$ Empirijske studije koje se bave ovim fenomenom mogu se pronaći u: Marie Lechler, "Employment shocks and anti-EU sentiment", European Journal of Political Economy, 59 (2019), pp. 266-295; Yann Algan et al., "The European trust crisis and the rise of populism", Brookings Papers on Economic Activity, 48 (2017), pp. 309-382; Luigi Guiso et al., "Global 
korona virusa uporedive sa posledicama krize evrozone, nalazi ovih studija treba da budu značajna pouka donosiocima odluka ukoliko imaju za cilj da očuvaju poverenje građana u evropski projekat.

Ono što je pozitivna promena u odnosu na prethodni poduhvat postkriznog menadžmenta jeste da je, uprkos oštrom suprotstavljanju Austrije, Švedske, Holandije i Danske, Evropski savet 21. jula 2020. otvorio je put u napredak usvajanjem predloga Evropske komisije za uspostavljanje fonda za ekonomski oporavak pod nazivom „EU sledeće generacije“ (Next Generation EU). Značaj ove odluke ogleda se u činjenici da je prvi put uspostavljena saglasnost da se fiskalni transferi finansiraju emitovanjem hartija od vrednosti zajedničkog duga država članica. ${ }^{26}$ Ovakva odluka podstiče očekivanja o tome da se ipak može pronaći rešenje za dugogodišnji kamen spoticanja evrozone - nemogućnost dogovora u cilju fiskalne koordinacije.

Na kraju, iako se kriza evrozone do pandemije smatrala posebnom u odnosu na sve prethodne krize koje su se sporadično dešavale u EU, i kriza korona virusa ima elemente koji je odvajaju od kriza koje joj prethode. Kriza korona virusa ne može se smatrati „strukturnom“ jer po svojoj suštini ne utiče na obim integracije, na funkcionisanje EU institucija i ne dovodi u pitanje članstvo neke od država članica (barem ne na direktan način). Nadalje, javlja se u području politike u kom EU ima veoma ograničenu nadležnost - sektoru javnog zdravlja. Takođe, kriza korona virusa podstiče tenzije između aktera na svetskoj sceni, dovodeći do rizika pogoršanja odnosa među njima. ${ }^{27}$ Naredno poglavlje bavi se upravo ključnim sporovima koje obeležavaju trenutne odnose EU sa njenim najvažnijim ekonomskim partnerima.

crises and populism: The role of Eurozone institutions", Economic Policy, 34(97), 2019, pp, 95-139, i Thiemo Fetzer, "Did austerity cause Brexit?" American Economic Review, 109 (2019), pp. 3849-3886.

${ }^{26}$ Više videti: European Commission, "Coronavirus: Commission proposes to provide $€ 81.4$ billion in financial support for 15 Member States under SURE", Press release, 24 August 2020. Internet: https://ec.europa.eu/commission/presscorner/detail/en/ip_20_1496. 10/06/2021.

${ }^{27}$ Eugenio Salvati, "Crisis and Intergovernmental Retrenchment in the European Union? Framing the EU's Answer to the COVID-19 Pandemic", op. cit., p. 10. 


\section{Odnosi sa najvažnijim ekonomskim partnerima}

Zašto su za ekonomski oporavak EU posebno važni dobri odnosi sa (najvažnijim) akterima na međunarodnoj ekonomskoj sceni? Multilateralna saradnja i međunarodna koordinacija, nalik na one u vreme globalne finansijske krize iz 2008. godine, neophodne su za uspostavljanje globalnog oporavka, budući da bi snažan recesioni udar na svetsku privredu u 2020. i trgovinski konflikti u svetu mogli da ugroze dostignut nivo globalizacije svetske privrede. ${ }^{28}$ Rast protekcionizma samo bi mogao imati kontraefekat, naročito u eri zavisnosti domaće aktivnosti privreda pojedinačnih država od međunarodne trgovine i priliva investicija, što je kriza korona virusa dodatno potvrdila.

Za EU je najvažnije da u kontinuitetu radi na unapređivanju odnosa prvenstveno sa SAD i Kinom iz više razloga. Prvo, činjenica da EU, SAD i Kina predstavljaju stubove današnjeg međunarodnog monetarnog sistema (MMS), u izvesnom smislu reformisanog nakon globalne finansijske krize, svedoči o kredibilitetu ove tri države i značaju njihove međusobne saradnje za uspostavljanje multilateralne strategije globalnog ekonomskog oporavka. ${ }^{29}$ Drugo, obim njihovih međusobnih trgovinskih i investicionih odnosa ukazuje na strateški značaj svakog od ovih aktera za ekonomski oporavak sva tri entiteta pojedinačno. Prema podacima Evropske komisije i UNCTAD-a za 2019. godinu, uvoz u EU27 iz SAD činio 12\% ukupnog EU27 uvoza, dok je na izvoz iz EU27 u SAD odlazilo 18\% ukupnog EU27 izvoza (isključujući promet na zajedničkom tržištu EU27). SAD su najznačajnije izvozno tržište za EU27 (na drugom mestu je Velika Britanija sa udelom od 14,9\%), a procentualni udeo uvoza iz SAD je na drugom mestu, odmah iza Kine (sa udelom od 18,7\%). Ipak, ukoliko posmatramo ukupnu vrednost trgovine, podaci potvrđuju da je SAD najznačajniji spoljnotrgovinski partner za EU, sa ukupnom vrednošću trgovine koja je za 1,4 procentualna poena viša od vrednosti trgovine sa Kinom kao drugim najznačajnijim partnerom (15,2\% i 13,8\%, respektivno). Takođe, Kina i SAD (tim redom) javljaju se kao dve države sa najvećim udelom u ukupnom svetskom izvozu, ali i kao najznačajnije uvozne destinacije na svetskom nivou (s tim što je SAD na prvom, a Kina na drugom mestu

\footnotetext{
${ }^{28}$ Radovan Kovačević, „Svetska privreda, trgovina Evropske unije i robni izvoz Srbije pre pandemije korona virusa (Covid-19)", op. cit., str. 20.

${ }^{29}$ EU, SAD i Kina identifikovane kao ključne zemlje MMS-a u: Ettore Dorruci and Julie McKay, The International Monetary System After the Financial Crisis, European Central Bank, February 2011.
} 
u svetskom uvozu). ${ }^{30}$ Što se tiče SDI, procenjuje se da je najviše investicija u toku 2019. poteklo iz Japana i Nemačke, a da se Kina i SAD nalaze na trećem i četvrtom mestu na globalnoj listi. Struktura ulaznih tokova SDI pokazuje da su u 2019. najvažnija destinacija za SDI bile SAD, a da se iza njih nalazi Kina. Preliminarne procene kretanja SDI za 2020. godinu pokazuju da je najviše SDI poteklo iz Luksemburga, a da se SAD i Kina nalaze na drugom i četvrtom mestu (Kina iza Japana). Takođe, procenjuje se da je u 2020. Kina pretekla SAD na mestu najznačajnije investicione destinacije. ${ }^{31}$ Sve ovo ukazuje na značaj SAD i Kine kako u međunarodnim trgovinskim, tako i međunarodnim investicionim tokovima uopšte, a naročito na njihov značaj za EU.

Kada se radi o odnosima EU i SAD, ova dva ekonomska aktera uživaju najširi obim bilateralnih trgovinskih i investicionih odnosa u okviru šireg međunarodnog ekonomskog sistema. Stepen njihovih veza kvalifikuje odrednicu tog odnosa kao najintegrisanijeg ekonomskog odnosa na svetu. Imajući u vidu veličinu ove dve ekonomije u apsolutnom smislu, kao i obim njihove međusobne trgovine, između ova dva ekonomska aktera sporadično dolazi do trgovinskih sporova (poznati su slučajevi kvota EU na uvoz banana iz karipskih zemalja i drugih bivših evropskih kolonija, čime se direktno uticalo na interese SAD; zabrane koje su na uvoz SAD nametnule institucije EU u slučaju teletine tretirane hormonima, zatim sporovi u oblasti biotehnologije - pre svega, genetski modifikovanih organizama - GMO, ali i novih informacionih tehnologija - deregulacija elektronskih baza podataka u SAD koja se kosi s pravilima EU o zaštiti privatnosti). Pored rešavanja ovih sporova, postoji prostor za unapređenje trgovinskih odnosa kroz smanjenje trgovinskih barijera, jer iako su carinske barijere niske i u proseku iznose ispod 3\%, necarinske barijere i dalje su značajna prepreka trgovini ova dva entiteta. Uspostavljanjem okvira za sveobuhvatne pregovore za definisanje Transatlantskog sporazuma o trgovini i investicijama (TTIP) iskazana je namera za uspostavljanje dogovora o daljoj liberalizaciji i povećanju tržišnog pristupa eliminacijom prepreka u trgovini robama i uslugama, ali i investicijama i procedurama vezanim za javne

30 Videti: European Commission, Trade Policy: United States, n.d. Internet: https://ec.europa. eu/trade/policy/countries-and-regions/countries/united-states/, 10/06/2021. i UNCTAD, Handbook of Statistics, 2020. Internet. https://unctadstat.unctad.org/EN/, 10/06/2021.

${ }^{31}$ OECD, Foreign Direct Investment Statistics: Data, Analysis and Forecasts, April 2021. Internet: https://www.oecd.org/investment/statistics.htm, 10/06/2021 
nabavke. ${ }^{32}$ Međutim, dolaskom Trampove (Donald Trump) administracije promenjen je pristup pregovorima sa EU, što se može uočiti i kroz činjenicu da su SAD odbile da ukinu subvencije svojim avio-prevoznicima, uprkos dogovoru sa EU zvaničnicima i uprkos nelojalnoj konkurenciji koja se tim subvencijama nameće avio-kompanijama iz EU. Repetitivno kršenje pravila STO od strane SAD opredelilo je odluku Saveta EU iz 15. aprila 2019. kojom je smernicama ispregovaranim u okviru TTIP ukinut status relevantnosti.

Početkom 2020. godine MMF je istakao da tenzije na relaciji SAD-EU mogu predstavljati veliki rizik po globalni ekonomski rast. Države članice EU optimistične su zbog promene američke administracije kada je reč o rešavanju sporova sa SAD u domenu ekonomskih odnosa. Veliki napredak u tom pogledu uočljiv je na primeru Francuske, koja je aprila 2019. uložila veto na nastavak trgovinskih pregovora sa SAD, a po inauguraciji Bajdena (Joseph Biden) pozvala na nastavak dijaloga sa SAD u cilju rešavanja trgovinskih sporova. Ono što ohrabruje jeste činjenica da je Bajden najavio ukidanje Trampovih carina i ponovno uspostavljanje STO kao glavnog trgovinskog autoriteta, odnosno poštovanje pravila međunarodne trgovine od strane SAD. To ukazuje da Bajden prepoznaje ne samo zajednički interes sa EU već i potrebu i nužnost unapređivanja ekonomskih odnosa "starih saveznika", naročito u kontekstu definisanja nacrta Investicionog sporazuma između EU i Kine početkom 2021. godine. ${ }^{33}$

I pored postignutog dogovora o investicionom sporazumu između Kine i EU, čini se da je opravdanije očekivati da naredni period obeleži popravljanje trgovinskih i investicionih odnosa EU sa SAD nego sa Kinom. Visoki predstavnik za spoljne poslove i bezbednosnu politiku EU Žozef Borelj (Josep Borrell), početkom 2020. istakao je četiri osnovna prioriteta globalne kooperacije EU. Jedan od definisanih prioriteta je ograničavanje ekonomske štete krize korona virusa kroz koordinisanje monetarnih i fiskalnih stimulusa na globalnom nivou i unapređivanje globalnih trgovinskih tokova. Borelj je naveo da u uspostavljanju

\footnotetext{
32 Videti: Kathleen R. McNamara, The End of the West? Cornell University Press, 2016. (Chapter 7: The Ties That Bind? U.S.-EU Economic Relations and the Institutionalization of the Transatlantic Alliance).

${ }^{33}$ O ekonomskim odnosima na relaciji EU-SAD videti: Andrea Matijević, „Ekonomski odnosi EU i SAD - izazovi i perspektive", Bilten o procesu pregovora o pristupanju Srbije Evropskoj uniji, br. 69/2021, Beogradska otvorena škola.
} 
globalne strategije ekonomskog oporavka računa i na Kinu. Ambasador EU u Kini Nikola Šapi (Nicolas Chapuis) navodi da je u različitim fazama pandemije zaista jeste bilo uzajamne podrške između Kine i EU. EU je početkom 2020, kada je pandemija u Kini bila na vrhuncu, pomogla doniranjem neophodne opreme, a Kina je tokom 2020. godine pomagala i državama EU i drugim državama sveta slanjem doktora i isporukom medicinske opreme. ${ }^{34}$ Činilo se da je kineska tzv. „korona-diplomatija“ imala uspeha i u unapređivanju ekonomskih odnosa sa EU, što je rezultiralo zaključivanjem pregovora za gorepomenuti investicioni sporazum (Comprehensive Agreement on Investment - CAl) krajem 2020. i definisanjem nacrta samog teksta sporazuma početkom 2021. godine.

Pa ipak, budućnost ovog sporazuma u trenutku pisanja ovog rada nalazi se „,na tankom ledu“. Naime, postupci kineskih zvaničnika prema muslimanskoj manjini Ujguri (Uyghurs), u pokrajini Sinđijang (Xinjiang), podstakli su zabrinutost zvaničnika EU zbog kršenja ljudskih prava. lako su SAD postupak Pekinga nad Ujgurima determinisale kao genocid i uvele trgovinski embargo Kini, EU je zauzela daleko manje konfrontacijski stav. Pažljivo kalibrisana lista sankcija, koju je EU objavila marta 2021, bila je usmerena prema četvorici kineskih zvaničnika u Sinđijangu i prema regionalnom birou javne bezbednosti. S obzirom na taj naizgled uzdržani pristup, EU je iznenadio neposredni kontranapad Pekinga. Evropski parlamentarci, koji su se našli na meti kineskih sankcija, zapretili su da neće ratifikovati investicioni sporazum između EU i Kine. Kineski zvaničnici su, ciljajući Evropski parlament, pokazali spremnost da žrtvuju investicioni sporazum da bi pokazali da EU nema pravo da se meša u nešto što shvataju kao pitanje interne bezbednosti Kine. Stoga je, samo nekoliko trenutaka nakon najavljivanja sankcija EU, Kina uvela kontramere usmerene ka pet vodećih članova Evropskog parlamenta - Pododboru parlamenta za ljudska prava i ka najvišim evropskim akademskim institucijama koje se bave Kinom. ${ }^{35}$

Kina je najavila zamrzavanje imovine pojedincima i stranim firmama ukoliko se budu pridržavali sankcija SAD, EU i Velike Britanije, a sve u cilju slanja poruke,

\footnotetext{
${ }^{34}$ Nicolas Chapuis, "EU-China relations in the time of COVID-19", Asia Europe Journal (2020), 18, p. 201.

${ }^{35}$ Stuart Lau, "China throws EU trade deal to the wolf warriors", Politico, 21. march 2021. Internet: https://www.politico.eu/article/china-throws-eu-trade-deal-to-the-wolf-warriors -sanctions-investment-pact/?utm_medium=Social\&utm_source=Facebook\&fbclid=Iw AR17CCZm6jNdBXXc_DYD5u19s9en0yJ9BD80RS7BS2dw44bqEtBZogh7VME\#Echobox=16 $16503479,10 / 06 / 2021 /$.
} 
uoči samita država Grupe 7 (G7), da se Kina suprotstavlja „zapadnoj hegemoniji i politici moći“, prema rečima kineskog ministra spoljnih poslova Vang Jia (Wang Yi). Završno saopštenje samita G7 u kome se na oštroj kritici našla Kina od koje lideri G7 zahtevaju unapređenje stanja ljudskih prava u Sinđijangu, očuvanje visokog stepena autonomije Hong Konga i mira i stabilnosti na Tajvanu, kineski zvaničnici ocenili su kao nedozvoljeno mešanje u unutrašnja pitanja, klevetanje Kine i narušavanje njenih interesa. ${ }^{36}$

Kakav će biti epilog ovog spora po ekonomske odnose EU i Kine ostaje da se vidi, ali kao što i kineski zvaničnici ističu, u jeku pandemije i globalnog ekonomskog usporavanja svakako je korisnije podsticati međunarodnu saradnju umesto podsticanja konfrontacija i podela. Uprkos spoznaji o nužnosti međusobne koordinacije u cilju ekonomskog oporavka, Kina je ipak najavila da neće dozvoliti narušavanje svojih interesa i da će te interese odlučno braniti.

\section{Zaključak}

EU se do sada pokazala otpornom na izazove koji su dovodili u pitanje njenu suštinu i cilj, podstičući rizik efektivne dezintegracije. Žan Mone (Jean Monnet), čije se ideje nalaze u osnovi Šumanove (Robert Schumann) deklaracije tvrdio je da će Evropa „,biti izgrađena u krizama i predstavljaće zbir rešenja usvojenih zarad tih kriza". Žak Širak (Jacques Chirac), nekadašnji francuski predsednik tvrdio je: „Istorija EU je istorija prevazilaženja kriza“. Mišljenje da su krize „dobre“ za EU ustalilo se u proevropski nastrojenoj javnosti. ${ }^{37} \mathrm{~Pa}$ ipak, čini se da je narativ prema kom krize podstiču integraciju EU simplifikacija koja i pre ove krize nije prošla empirijski test. Istorija EU pokazuje da postoje i krize koje su se završile sa očiglednim neuspehom, poput odbacivanja ideje o uspostavljanju Evropske odbrambene zajednice (budući da se ni danas ne može govoriti o integraciji u

\footnotetext{
${ }^{36}$ Videti: Milenko Pešić, „Kontraofanziva Pekinga protiv zapadnih sankcija“, Politika, 12. 06. 2021. Internet: http://www.politika.rs/scc/clanak/481166/Kontraofanziva-Pekinga-protivzapadnih-sankcija?fbclid=IwAR110EYpyJfb9fvLGNni615zWItdK9JNRUPEIYB7TBqBladntG _LwcjSoig, 12/06/2021, i: Politika, „Kina oštro osudila saopštenje lidera zemalja članica G7", Politika, 14.06.2021. Internet: http://www.politika.rs/scc/clanak/481218/Kina-ostroosudila-saopstenje-lidera-zemalja-clanica-G7, 14/06/2021.

37 Prema: Dragana Dabić, „Fenomen krize u evropskoj integraciji“, Međunarodna politika, br. 1177, januar-mart 2020, str. 5-29.
} 
oblasti odbrambene politike, već samo o „labavoj saradnji“). ${ }^{38} \mathrm{~S}$ druge strane, jačanje EU institucija pod uticajem krize u uslovima slabljenja nadležnosti država članica može rezultirati dezorganizacijom koja opet preti da dovede do osujećivanja spremnosti EU da se nosi sa velikim izazovima. ${ }^{39} \mathrm{U}$ tom smislu, kriza korona virusa predstavlja pravi test po EU pre svega u političkom, a zatim i u ekonomskom smislu.

Za opstanak EU je osim rešavanja finansijskih problema prouzrokovanih krizom korona virusa potrebno i adresiranje dugoročnih, strukturnih problema koji vode do divergencije među članicama EU. ${ }^{40}$ Drugim rečima, osim brige za ponovnim uspostavljanjem pozitivnih stopa ekonomskog rasta (s obzirom na to da je stopa rasta realnog BDP-a u 2020. godini bila u minusu za čak 6,1\%), potrebno je pronaći način da se uspostavi što veća koordinacija fiskalnih politika država članica (evrozone prvenstveno, ali i EU u celosti). Time bi se na najefikasniji način mogao rešiti problem dugova preterano zaduženih zemalja, jer bi koordinacija vodila povećanju fiskalne discipline. U tom smislu naročito je značajno što se ovom problemu pristupilo u okviru definisanja strategije za saniranje posledica krize korona virusa kroz izdavanje tzv. korona obveznica koje u pravom smislu reči simbolizuju konačnu posvećenost zajedničkom rešavanju problema fiskalne neodgovornosti.

Briga o međunarodnom statusu takođe je važna kao deo strategije ekonomskog oporavka, i u tom smislu poseban izazov za EU biće ne samo popravljanje međunarodne trgovinske i investicione pozicije (koje su u izvesnom smislu pogođene krizom korona virusa, čak i više nego krizom evrozone) već i rešavanje problema na relaciji EU-SAD i EU-Kina. Sa Bajdenom na poziciji predsednika SAD budi se nada u pomirenje „starih saveznika“ na ekonomskom planu, ali pretnje Kine da će učiniti sve da zaštiti svoje nacionalne interese i da se suprotstavi pritisku. EU i SAD bude opravdane strepnje ne samo po sudbinu ispregovaranog Investicionog sporazuma, već i po ekonomske odnose Kine i EU u budućem periodu uopšte.

\footnotetext{
${ }^{38}$ Ibid., str. 26.
}

${ }^{39}$ Otmar Issing, "The COVID-19 crisis: A Hamilton moment for the European Union?", op. cit., p. 347.

${ }^{40}$ Giuseppe Celi, Dario Guarascio and Annamaria Simonazzi, "A fragile and divided European Union meets Covid-19: further disintegration or 'Hamiltonian moment'?”, op. cit., p. 414. 
Ipak, da ,svetlo na kraju tunela“ nije samo uobrazilja potvrđuju i projekcije MMF-a o ekonomskom rastu od 4,4\% za 2021. godinu (radi se o rastu realnog BDP-a), reuspostavljanju pozitivne trajektorije rasta već 2022. uz stopu rasta od $3,9 \%$ i stabilizaciji stope rasta na 1,6\% u 2024. i 2025. godini. Uprkos realizovanom padu ekonomske aktivnosti i na unutrašnjem i na međunarodnom planu u 2020. godini, optimistično bi se moglo zaključiti da će period oporavka od efekata krize pandemije virusa Kovid 19 nastupiti brže nego što se to na početku moglo očekivati.

\section{Literatura}

Algan, Yann et al., "The European trust crisis and the rise of populism", Brookings Papers on Economic Activity, 48 (2017), pp. 309-382.

Anderson, Julia, Tagliapietra, Simone and Wolf, Guntram B., "Rebooting Europe: A Framework for a Post Covid-19 Economic Recovery", Policy Brief Issue 1, May 2020, Bruegel.

Barbier-Gauchard, Amélie et al., "Towards a more resilient European Union after the COVID-19 crisis", Eurasian Economic Review, volume 11 (2021), pp. 321-348.

Bjelić, Predrag, Međunarodna trgovina, Ekonomski fakultet, Beograd, 2018.

Camous, Antoine and Claeys, Grégory, "The Evolution of European Economic Institutions During the Covid-19 Crisis", European Policy Analysis, 2020:6, pp. 328-341.

Celi, Giuseppe, Guarascio, Dario and Simonazzi, Annamaria, "A fragile and divided European Union meets Covid-19: further disintegration or 'Hamiltonian moment'?", Journal of Industrial and Business Economics, volume 47 (2020), pp. 411-424.

Chapuis, Nicolas, "EU-China relations in the time of COVID-19", Asia Europe Journal (2020) 18, pp. 201-203.

Dabić, Dragana, „Fenomen krize u evropskoj integraciji“, Međunarodna politika, br. 1177 januar-mart 2020, str. 5-29.

Dorruci Ettore and McKay, Julie, The International Monetary System After the Financial Crisis, European Central Bank, February 2011. 
Fetzer, Thiemo, "Did austerity cause Brexit?" American Economic Review, 109 (2019), pp. 3849-3886.

Guiso, Luigi et al., "Global crises and populism: The role of Eurozone institutions", Economic Policy, 34(97), 2019, pp. 95-139.

Issing, Otmar, "The COVID-19 crisis: A Hamilton moment for the European Union?", International Finance, Volume 23, Issue 2, Summer 2020, pp. 340-347.

Kovačević, Radovan, „,Svetska privreda, trgovina Evropske unije i robni izvoz Srbije pre pandemije korona virusa (Covid-19)", Ekonomske ideje i praksa, broj 38, septembar 2020, str. 7-25.

Krugman, Paul R., Obstfeld, Maurice and Melitz, Marc J., International Economics - Theory and Policy, Pearson Education Limited, 2018.

Ladi, Stella and Tsarouhas, Dimitris, "EU economic governance and Covid-19: policy learning and windows of opportunity", Journal of European Integration, Volume 42, 2020, pp. 1041-1056.

Lechler, Marie, "Employment shocks and anti-EU sentiment", European Journal of Political Economy, 59 (2019), pp. 266-295.

Maliszewska, Maryla, Mattoo, Aaditya and Van der Mensbrugghe, Dominique, "The Potential Impact of COVID-19 on GDP and Trade: A Preliminary Assessment", World Bank Policy Research Working Paper No. 9211, April 2020.

Matijević, Andrea, „Ekonomski odnosi EU i SAD - izazovi i perspektive“, Bilten o procesu pregovora o pristupanju Srbije Evropskoj uniji, br. 69/2021, Beogradska otvorena škola.

McNamara, Kathleen R., The End of the West?, Cornell University Press, 2016.

Praščević, Aleksandra, „Ekonomski šok pandemije Covid 19 - prekretnica u globalnim ekonomskim kretanjima", Ekonomske ideje i praksa, broj 37, jun 2020, str. 7-22.

Salvati, Eugenio, "Crisis and Intergovernmental Retrenchment in the European Union? Framing the EU's Answer to the COVID-19 Pandemic", Chinese Political Science Review, volume 6 (2021), pp. 1-19.

Salvatore, Dominik, Međunarodna ekonomija, Centar za izdavačku delatnost Ekonomskog fakulteta, Beograd, 2014.

Samardžić, Slobodan, „Evropska unija između krize i dezintegracije“, Pravo i društvo, Broj 1, 2012, str. 9-26. 
Samardžić, Slobodan, „Evropska unija u lavirintu krize“, u: Slobodan Samardžić i Ivana Radić-Milosavljević (ur.), Kriza Evropske unije, Službeni glasnik, Beograd, 2013.

Samardžić, Slobodan, „Jedan političko-realistički pogled na današnju Evropu i mesto Nemačke u njoj", pogovor u: Minkler, Herfrid, Sila u središtu: Novi zadaci Nemačke u Evropi, Albatros Plus, Beograd, 2016.

\title{
ECONOMIC CHALLENGES FOR THE EUROPEAN UNION IN THE POST COVID-19 PERIOD
}

\begin{abstract}
The crisis caused by the COVID-19 pandemic, in addition to health consequences, has created far-reaching political, social, but above all economic consequences on a global level. This paper seeks to offer an overview of the consequences of this crisis on the economic flows of the European Union. The consequences of the pandemic crisis will be analyzed through the values of macroeconomic indicators for 2020: changes in economic growth rates observed through the growth of the real gross domestic product, changes in inflows and outflows of foreign direct investment, as well as changes in international trade observed through imports and exports of goods and services. It will be pointed out that the consequences of changes in these macroeconomic trends are unevenly distributed among the EU member states and that some countries have experienced a greater decline in economic performance than others. Summarizing the findings of such an analysis will offer a basis for predicting economic trends in the future. Namely, in the short run, it can be optimistically expected that in 2022, the European Union will re-establish positive growth trajectories. On the other hand, if we look at the long term, in order for the crisis of governance of the European Union (existing even in the economic sphere) to be resolved with a positive outcome, it is necessary to resolve inherent instabilities in the Eurozone. Besides this, in order to establish economic recovery in the long run, it is necessary to approach solving problems in relations with economic partners. In that sense, special importance should be given to the improvement of trade and investment relations with the United States and China. Today, the EU, the US and China represent the three pillars of the international monetary system and enjoy the widest scope of mutual economic relations on which the economic success of all three economic giants is individually based. Nevertheless, there is room for improvement in the EU's relations with both the US and China, on which not just EU stability per se, but also world economic stability in the future may also be dependent.
\end{abstract}

Keywords: European Union, COVID-19, economic growth, foreign direct investment, international trade, The United States, China. 